tredje person som själva brobyggaren, Per Henrik Ling, »den svenska gymnastikens fader «. Hos Ling finner Aronson en skapelseteologi som tar vara på tanken att människokroppen är Guds goda skapelse. Just på gymnastikens område har skett möten mellan svenska akademiker och danska folkhögskoleelever. Människan som kropp, själ och ande betonas av Ling.

Liksom Pedersen betonar Aronson att Grundtvig kunde ge hedendomen ett mänskligt ansikte och se gudsbilden i människan även utanför det kristliga sammanhanget.

Aronson citerar Ernst Trier som menar att gymnastiken blir ett medel som kan hjälpa fram gudsbilden i människan, så att människan skiljer sig från djuret. Lings uttryck en gudsbilden värdig människotyp blir slutvinjetten $\mathrm{i}$ Aronsons uppsats. Grundtvig och Geijer, och mellan dem P.H. Ling och gymnastiken som en bro - en andefylld gymnastik som hjälper människan att se sig som en Guds skapelse, knuten till en dimension utanför henne själv.

Boken är väl värd att läsa, och den ger antydningar som hjälper den uppmärksamme läsaren att förstå de kulturella skillnaderna mellan Danmark och Sverige, men också att se eller ana en bro som förenar de bägge ländernas kultur och kristendomstolkning. Om något negativt skall sägas om boken så är det att man har slarvat med korrekturläsningen och att det bort finnas en presentation av författarna. Kanske kunde också Grundtvigs och Geijers födelse- och dödsår angetts redan i bokens början. Men budskapet går fram, och det är det viktigaste.

\title{
Kvartetten Kingo, Brorson, Grundtvig og Ingemann
}

\section{Af Hans Boas}

Et kor af stemmer. Tematiske lasninger af salmebogen. Redigeret af Kirsten M. Andersen. Forlaget Anis. København 1997. 266 sider. 249 kr.

"Salmebogen er, kunne man sige, et kor af stemmer, der slår bro mellem de bibelske skrifter og søndagens aktuelle menighed.« Sådan indleder Kirsten M. Andersen disse tematiske læsninger af Den danske Salmebog. I ni artikler belyser hver af forfatterne udvalgte salmer i en beskrivelse af det frelseshistoriske perspektiv, i analyser af hjertet som metafor, i tolkninger af døgnets vekslen mellem dag og nat, af landskabers og årstiders skiften. Mange af salmerne sammenkæder de forskellige motiver, hvorfor de samme salmer da også indgår i flere af artiklerne. Det har været hensigten at lade salmebogen fremstå som »et kor af stemmer«, men i næsten alle artiklerne er det de fire 
store: Kingo, Brorson, Grundtvig og Ingemann, der optager pladsen, selv om Petter Dass og Jakob Knudsen da også inddrages et par steder, og det er godt nok sådan. For det kan jo tages som et udtryk for, at det at skrive en salme, der har kvalitet, og som er anvendelig, kræver store ånder. Der er mange stærke salmer i vores salmebog - men der er sandelig også meget, der ikke er værd at bruge tiden på. I denne anmeldelse er det især analyserne af Grundtvigs salmer, der har interesse.

Jørgen Kjargaard fører i sin artikel læseren gennem salmehistoriens anvendelse af Paradis-motivet. I reformationstidens salmer videreførtes middelalderens negative syn på Paradiset som syndefaldets sted. Men i ortodoksien bliver Jesu menneskevordelse den troendes nye indgang til Paradiset. For Kingo er Paradiset stadig det bibelske, altså syndefaldets historiske skueplads. I pietismens tid er Paradiset en forestilling om den fremtidige lyksalighed i de himmelske sale; den troende længes efter et bedre Paradis end det, som blev fordærvet. Paradis-motivet forsvandt helt fra rationalisternes Evangeliskkristelig Psalmebog. Paradiset er ikke bare tabt - det findes slet ikke. Hos den store banebrydende romantiker Adam Oehlenschläger dukker Paradisforestillingen op igen, men kun som en individuel og privat forestilling. Oehlenschläger aner blot de ubekendte strande ved det tabte Paradis. For Ingemann er det bibelske Eden tabt. Men med Kristus er Paradisvejen fundet igen. Dog er pilgrimsvejen lang at gå, for lysets hjem ligger langt herfra. For Grundtvig er det store spørgsmål: Befinder Paradiset sig kun i fortiden eller i det hinsides, eller er det også en nutidig realitet? Grundtvig når frem til, at Paradiset åbnede sig i den have, hvor Jesu grav stod tom. Grundtvig gør op med den forudgående epokes skildring af Paradiset som et drømmebillede. Man skal ikke tale om Paradiset som noget, vi har tabt i fortiden; nej, det genvundne Paradis skal forkyndes som nutid, som tro og håb og kærlighed. I de salmer, der er skrevet efter Grundtvig, er der ikke blevet tilføjet noget væsentligt om Paradiset, anfører Jørgen Kjærgaard. Udviklingslinjen går fra den bibelske beskrivelse af Paradiset $\mathrm{i}$ senmiddelalderen over en gradvis opløsning af det bibelske verdensbillede til en spiritualisering af Paradiset, som dog med Grundtvig har fået sin rette betydning i gudstjenestens sammenhæng formidlet i forkyndelsen.

I Jakob Ballings korte artikel om exodusmotivet i salmerne beskrives det historiske såvel som det nutidige aspekt ved vandrings- eller bevægelsesmotivet, anskueliggjort $\mathrm{i}$ jødernes påskemåltid og i de kristnes overgang fra den gudfjendtlige verden til frelsen i Jesus Kristus. I den forbindelse fremhæves Grundtvig som den af salmebogens forfattere, der har formået at sammentænke Det Gamle Testamente, Det Nye Testamente, de kristnes nutid og deres fremtid. Grundtvig er, for at bruge Ballings eget udtryk, "mere oldkirkelig end oldkirken selv, hvad angår denne vilje til frelseshistorisk koncentration « (s. 52). Forskellen på den jødiske og den kristne tolkning af udgangs- eller overgangsmotivet applikeret på menneskelivet ligger i det forhold, at den kristnes bevægelse gennem livet forudsætter, at en guddomme- 
lig bevægelse allerede har fundet sted i og med Gudsordets fornedrelse i Jesus Kristus.

Hos Kingo og Brorson finder man ifølge Lisbeth Smedegaard Andersen en angivelse af salmens »jeg" som et kollektivt begreb, mens Grundtvig anvender »jeg'et« i sine salmer i en anderledes personlig betydning. I Grundtvigs »jegsalmer « føres vi af digteren igennem en anråbelse af Gud og en beskrivelse af den bedendes egen sorg og fortvivlelse frem til en oplevelse af bønhørelse i form af et trøstende ord. Dette påvises i en analyse af salmen »Vor Herre! til dig må jeg ty«. Grundtvigs egen udvikling som menneske med kriser og perioder med klarsyn og optimisme er med andre ord afgørende for forståelsen af hans salmer om Guds forsyn. Begrundelsen for, at han må arbejde på denne måde med forsynstanken, er ifølge Lisbeth Smedegaard Andersen, at det fælles fundament på Grundtvigs tid er forsvundet - der er sket en afsakralisering af verden, og ethvert menneske må nu skabe sig sit eget univers. Grundtvig har påtaget sig at skabe en ny orden i troens univers, og det kan han kun, når han inddrager sig selv. Det nye fundament er dog ikke hans eget indre, men den bibelske verden. »Mere end nogen tidligere salmedigter må han derfor inddrage den tredje person i Treenigheden, nemlig Helligånden, Talsmanden, der hos Grundtvig tilkendes en levende og central rolle i Guds forudseende omsorg « (s. 80).

Med Karin Friis Plums artikel om salmens erotiske metaforik bevæger vi os fra det rent åndelige og uhåndgribelige til kærligheden forstået som en følelse, der omfatter hele mennesket. Her er det kroppen, der er i fokus. I forlængelse af denne forståelse definerer Karin Friis Plum salmen som »menighedens intime henvendelse til sin Gud « og som »kærlighedssprog «. De gammeltestamentlige klagesalmer udtrykker længsel og råb - og er dermed ifølge Karin Friis Plum kærlighedserklæringer med erotisk indhold. Uden den erotiske metaforik kan der overhovedet ikke skrives salmer, for salmen lever af den dybe længsel efter noget andet/en anden. Vejen til indsigt i dette forhold går naturligvis gennem den grædende, kyssende, sansende og selvhengivende kvinde. I en sammenlignende analyse mellem Brorsons og Grundtvigs anvendelse af den erotiske metaforik i salmedigtningen fremhæver Karin Friis Plum Brorsons brug af alle sanser i sine beskrivelser. Hos Grundtvig lugtes og smages der ikke så meget. »Grundtvig nærmer sig en psykologisk-romantisk forståelse af hjertet, som er anderledes end Brorsons meget konkrete forståelse af hjertet som et sansende subjekt.« (s. 106)

Christian Thodbergs artikel om hjertemetaforen i Brorsons og Grundtvigs salmedigtning er en fin modvægt til Karin Friis Plums påstand om Grundtvigs abstrakte anvendelse af de erotiske metaforer i sine salmer. Thodbergs artikel er ganske vist ikke skrevet som en replik til Karin Friis Plum, men som opposition til Troels Nøragers doktordisputats »Hjerte og psyke«. Thodbergs metode er den samme, som man finder i analyserne i artikelsamlingen »For sammenhængens skyld « (Institut for Praktisk Teologi, Århus 1977), hvor Erik Krebs Jensen i sin tid skrev en særdeles læseværdig artikel om Hjertets 
gudbilledlighed på baggrund af Grundtvigs salmer og prædikener. Men her er der altså tale om en sammenlignende analyse af Brorsons og Grundtvigs brug af hjertemetaforen. Thodberg kritiserer Nørager for i sin analyse af hjertebegrebet hos Brorson kun at anskue forholdet til Gud som et kærlighedsforhold. Ifølge Thodberg betragter Brorson også hjertet som stedet for kærlighedsløshed og oprøret mod Gud. Men Brorson mener tillige, at boden såvel som forbedringens vej er indskrevet i hjertet som en anvisning på aktiv meditation over Jesu lidelse. Den åndelige forening med Gud, der følger af denne bodskamp, er dog ikke i overensstemmelse med ortodoks luthersk teologi, hvor tilsigelsen af syndernes forladelse $i$ evangeliet og sakramenterne har altafgørende betydning.

Hos Grundtvig kan hjertebegrebet ikke isoleres fra sproget, og dermed fra evnen til at tale og høre. For Grundtvig er Rom. 10,8-10 det centrale bibelsted i tolkningen af hjertets gudbilledlighed. Kombinationen af hjertets tro og mundens bekendelse opfattes af Grundtvig som en pagt, hvilket stemmer overens med hans mageløse opdagelse af den apostolske trosbekendelse, som anvendt ved dåbshandlingen som hjertets genlyds ja - har konstituerende betydning for gudsforholdet. Hvor Brorson lader frelsen komme an på det bodfærdige hjertes selvbekræftelse, opfatter Grundtvig hjertet som det modtagende og lyttende og som det sted, hvor dåbspagten bekræftes. »I modsætning til Brorson tages sakramenternes indhold og ord for kontant pålydende; de skal ikke først sorteres af en prøvelse af hjertets oprigtighed « (s. 135). En anden væsentlig forskel på Brorsons og Grundtvigs opfattelse af hjertet består i deres forskellige syn på syndefaldets virkninger. Grundtvig insisterer på, at der er en rest af gudbilledligheden tilbage hos hjertet. Hjertet kan stadig længes og bevæges af »Himmelens røst», men er helt afhængigt af, at Guds Ord og Ånd gør sin virkning. Hos Brorson er det den troendes længsel, der skal lukke hjertet op for Frelseren. Hos Grundtvig hedder det, at Jesus ved dåben er blevet genfødt som herlighedens håb i hjertet, så han er der allerede! Afsluttende slår Thodberg fast, at hjertet for både Brorson og Grundtvig er gudstjenestens sted, men hos Brorson lægges der i så høj grad vægt på den åndelige gudstjeneste, at det bliver på bekostning af den faktiske gudstjeneste. Det forkyndte ords forrang, sådan som vi kender det fra den lutherske gudstjeneste bliver derved truet. Hos Grundtvig klynger hjertet sig netop til dette forkyndte ord og svarer igen med den lydelige bekendelse og lovsang.

Efter Troels Nøragers artikel om den religiøse inderlighed hos Brorson følger Carsten Bach-Nielsens redegørelse for anvendelsen af lys- og mørkemetaforer i Den Danske Salmebog. Hos Kingo opfattes natten som det tidsrum, hvor sjælen hviler i graven sammen med Jesus. Om natten er man altså tæt forbundet med sin frelser i en afdøen fra synden. Næste morgen, hvor lyset vækker kroppen, opstår mennesket som en enhed af sjæl og legeme som et lysets barn. Hos Brorson ses der helt bort fra det udvortes; sandheden findes kun i det indvortes og er skjult for verden. Der skal derfor en indre oplysning til, for at synden kan overvindes. Der er altså ikke længere nogen umiddelbar 
sammenhæng mellem den konkrete solopgangs lys og tanken om, at Guds nåde er ny over mennesker hver morgen. Jesus skal som lys og sol opgå over sjælen. "Hos Kingo er oplysningen passiv, hos Brorson resultat af en aktiv handling, en udrensning, en oprustning ved dagtide« (s. 207). Brorsons opgør med rationalismens forstålse af oplysning ved fornuftens hjælp følges op af Grundtvig, der her på dette punkt gør fælles sag med Brorson. Hos Grundtvig sammenkædes Ordets opstandelse og Helligåndens oplysning af menigheden: "Som guld er den årle morgenstund, når dagen opstår af døde.« Grundtvig kombinerer modsætningspar på en ny og overraskende måde ved hjælp af metonymier (ord der låner betydning af hinanden). Bach-Nielsen foretager en underfundig sammenligning af Ingemann og Grundtvig: Ingemann er uden Grundtvigs "grovkornede, gammeltestamentlige, nærmest brovtende, højstemthed. Ingemann er Biedermeier med blikket rettet ud over søen og landskabet fra villaen ved Sorø Akademi. Hvor Grundtvig er X-large er Ingemann Small« (s. 210). If $ø$ lge Bach-Nielsen er Ingemann anderledes fri til at kombinere naturlyrik med den ældre emblematiske opfattelse af naturen.

I Henrik Wigh-Poulsens artikel om landskabsbilleders anvendelse i salmerne kan man få hjælp til et mere nuanceret billede af forholdet mellem Grundtvig og Ingemanns salmer. Wigh-Poulsen citerer fra Grundtvigs anmeldelse af Ingemanns Højmessesalmer fra 1825, trykt i Theologisk Maanedsskrift. Heri roser Grundtvig Ingemann for - i modsætning til Oehlenschläger - at have aflagt den romantiske digters hovmod og have ofret sine digtergaver på kirkens alter. "Her er altså endelig noget af det, Grundtvig har ventet på. Ingemann har genfundet den oprindelige "Kirkelige Grund-Tone«, som det lyder i et udkast til selve anmeldelsen« (s. 226). Grundtvig betonede gang på gang nødvendigheden af at skrive salmer ud fra en tradition med henblik på, at salmerne skulle anvendes i en menighed. Wigh-Poulsen priser da også Grundtvig for hans evne til at bygge bro mellem den traditionelle opfattelse af naturen som Guds bog og den moderne opfattelse af naturen som et landskab. Hvor naturen hos Kingo og Brorson har en tjenende og afbildende funktion som illustration af det, troen omfatter, lader Grundtvig under inspiration af den oldkirkelige digtning naturen selv tage del i lovprisningen af Gud. Det er ikke kun hos mennesket, men tillige hos fuglen, blomsten og bøgeskoven, at der findes en guddomsgnist og en paradisbestemthed, der muliggør skaberværkets sang og lovprisning til Guds ære. Og det er ikke kun noget, der hører fortiden til. Den profetiske Grundtvig er ikke i tvivl: Helligånden er virksom på ny. Det er "Aandens Sommertid i Danmark«. Wigh-Poulsen illustrerer dette synspunkt i en analyse af »Blomstre som en rosengård og $» I$ al sin glans nu stråler solen«. Med henvisning til Christian Thodbergs analyser af "Gudsbarnets Vuggesang « understreger Wigh-Poulsen Grundtvigs fremhævelse af »det hjemlige «. Dette motiv findes også i de salmer, hvor Grundtvig inddrager den danske natur i en beskrivelse af Guds rige: »Og han formår at bringe sin menighed samme sted hen - til faderhjemmet, til barnekår, til det kendte landskab, hvor alt taler om Guds kærlige almagt« (s. 240). 
Den sidste artikel i bogen er Erik Skyum-Nielsens beskrivelse af nutidens salmedigteres kvaler med at finde et rum, som salmen kan leve og ånde $i$, når nu den moderne videnskab har afsakraliseret verden og afmystificeret Himlen. "Skaberværket ser ud til at skrumpe«, hævder Skyum-Nielsen. Rummet er blevet planløst og åndsforladt, tynget af materialisme og naturvidenskabens lovmæssigheder. Og det frirum, der er blevet tilovers, forkyndelsens rum, er ganske enkelt for lille, eftersom den kristne tolkning af tilværelsen ligger i åben strid med andre mere rationelle måder at betragte verden på.

Skyum-Nielsen fremhæver Grundtvig som en poet, »der tør give billedet plads, og som evner at lære af det, således at hans forkyndelse føjer sig efter hans digteriske vision « (s. 256). Det, som Grundtvig formår i sin salmedigtning, er at inddrage hele rummet - Himlen begynder her og nu - uendeligheden - eller evigheden - er en del af salmens univers, samtidig med at Grundtvig er solidt funderet i det bibelske stof. Men Grundtvigs salmer bliver ikke fremmede og fjerne. Han relaterer sine poetiske billeder til den velkendte natur, så salmen føles hjemlig og vedkommende, samtidig med at den udvider rummet til uendelighedsperspektiv.

»Et kor af stemmer « er en spændende og ny tilgang til Den danske Salmebog. De vidt forskellige perspektiver, der ofte anlægges på de samme salmer, udvider læserens forståelse for betydningen af den kulturskat, vi har i disse digte, der er skrevet af tro til tro, ikke for at blive læst, men for at blive sunget af menigheden ved gudstjenesten. Ved læsningen af de ni artikler vækkes sansen for poesien, når den er bedst, nemlig dér hvor ordene åbner perspektivet - gør rummet større, ja uendeligt, samtidig med at det hjemlige, velkendte og nære fastholdes. Et par af artiklerne slutter med at overveje, om det overhovedet er muligt at skrive gode og vedkommende salmer i dag. Hvor store er ånderne? $\mathrm{Og}$ er det muligt $\mathrm{i}$ dag $\mathrm{i}$ et poetisk sprog at udtrykke troen på en sækular baggrund? Ak ja, vi venter stadig spændt på at se, hvad salmebogskommissionen når frem til! 